\title{
Growth and Yield of Okra with Rock-Phosphate - Amended Organic Fertilizer
}

\author{
Eyitayo A. Makinde ${ }^{1}$ \\ ${ }^{1}$ Department of Horticulture, Federal University of Agriculture, Abeokuta, Nigeria \\ Correspondence: E. A. Makinde, Department of Horticulture, Federal University of Agriculture, Abeokuta, \\ Nigeria. E-mail: eamakinde@yahoo.com
}

Received: July 1, 2013 Accepted: August 21, 2013 Online Published: September 15, 2013

doi:10.5539/jas.v5n10p221 URL: http://dx.doi.org/10.5539/jas.v5n10p221

\begin{abstract}
Phosphorous supply from organic manures for okra production can be insufficient for optimal fruit yield. The growth and yield of okra (Variety: NHAe 47-4) were assessed in field experiments with an organic fertilizer made from cowdung (CD), fortified with Ogun Rock Phosphate (ORP). The ORP was applied sole at $100 \mathrm{~kg} \mathrm{ha}^{-1}$ and also with each of 2.5; 5.0; 7.5 and $10.0 \mathrm{t} \mathrm{ha}^{-1}$ cowdung. There was a standard check of NPK 20-10-10 applied 2 weeks after planting at $400 \mathrm{~kg} \mathrm{ha}^{-1}$ and an unfertilized control., Average number of leaves per plant, stem diameter and plant height were all similar, with 4 weeks growth. Average plant leaf area was however higher with ORP added to either 7.5 or $10.0 \mathrm{tha}^{-1} \mathrm{CD}$, relative to either sole ORP or the unfertilized treatments. At 8 weeks after planting, plant height was highest with $10.0 \mathrm{tha}^{-1} \mathrm{CD}+\mathrm{ORP}$ and was comparable only with plants from $7.5 \mathrm{tha}^{-1}$ CD + ORP application. Plant stem girths were similar with all ORP applications. Number of leaves per plant and average leaf area were highest with $10.0 \mathrm{tha}^{-1} \mathrm{CD}+\mathrm{ORP}$. Applications of 2.5; 5.0 and $7.5 \mathrm{t} \mathrm{ha}^{-1} \mathrm{CD}+\mathrm{ORP}$ had comparable leaf areas. Application of $10.0 \mathrm{t} \mathrm{ha}^{-1} \mathrm{CD}+\mathrm{ORP}$ gave the highest okra fruit yield which was comparable with yields from $2.5 ; 5.0$ and $7.5 \mathrm{tha}^{-1} \mathrm{CD}+\mathrm{ORP}$ that ranged from 2.92 to $3.05 \mathrm{tha}^{-1}$. Pod length and pod circumference were significantly higher with ORP +10.0 or $7.5 \mathrm{tha}^{-1} \mathrm{CD}$. Plants from the unfertilized control treatment had significantly shorter pods with lower circumference than all the fertilized plants. Okra fruit yield is significantly increased with organic fertilizer fortification with ORP.
\end{abstract}

Keywords: Abelmoscus esculentus, fertilizer amendment, fruit yield, pod size

\section{Introduction}

Use of fertilizers to sustain intensive cropping systems on most tropical soils has been reported necessary due to their low nutrient status (Adetunji, 1991). The importance of phosphorus (P) as a yield - limiting plant nutrient in many Nigerian soils has been well established (Adepetu, 1983; Adetunji, 1994). However, there still exists an inadequacy in basic information required for phosphorus fertilizer rates for annual or seasonal maintenance of most tropical soils. To date, very little is known about the supply of P requirement of okra cropping. The high cost of soluble phosphate fertilizers, has induced considerable interest in the utilization of rock phosphates (RP) (Nnadi and Haque, 1998). The use of locally-available rock phosphates has been adopted as alternatives. Ogun rock phosphate (ORP) is an indigenous phosphate source in Nigeria. The phosphorous content is $25-31 \% \mathrm{P}_{2} \mathrm{O}_{5}$ and has low solubility (Akande, 2005; Adetunji, 2005). Considerale concerns have been expressed on the effectiveness of the rock phosphates for direct application. Direct application of ground rock phosphates has however been proved to be beneficial to crops. Many studies have been conducted on amending rock phosphates to increase their immediate $\mathrm{P}$ availability and also possibly to enhance their rate of dissolution after application to soil. Use of composts of RPs with agricultural wastes is known to increase solubility of rock phosphates (Akande et al., 2008; Singh \& Amberger, 1990). The degree of solubilization of phosphorus of a given RP varies with the kind and the rate of decomposition of the organic material used (Bangar et al., 1985). Grain yields of maize and cowpea from P-treated plots were significantly higher than from untreated plots (Akande et al., 2011). Evaluating the comparative effects of urea and poultry manure (PM) on solubilization of rock phosphate and on the growth and yield of okra, Akande et al. (2003) reported use of rock phosphate combined with poultry manure and to a lesser degree urea, improved the growth and yield of okra compared to when the materials were used individually. Applications of RP + urea and RP + poultry manure were also found to increase soil Available P by between 112 and $115 \%$ and 144 to $153 \%$, respectively. 
This study was conducted to determine the optimum ratio of amending Ogun RP with cowdung for optimum growth and yield of okra.

\section{Materials and Methods}

Field experiments were conducted in 2010 and 2011 at Abeokuta, Ogun State, Nigeria (latitude $7^{\circ} 12^{\prime} \mathrm{N}$; longitude $3^{\circ} 20^{\prime} \mathrm{E}$ ) at $100 \mathrm{~m}$ above sea level. There is usually a bimodal rainfall pattern, with a long rainy season between March and July and a short rainy season, usually from September to early-November, after a short dry spell in August and a longer dry period from December to February. The soil was an Aquic Arenic Haplustalf that had been cultivated for four years with arable crops. The site was ploughed and harrowed. Ten core soil samples were randomly collected from the top $20 \mathrm{~cm}$ depth prior to cropping, bulked and analyzed for chemical and physical properties. Samples were air dried, crushed and passed through a $2 \mathrm{~mm}$ sieve. Routine analyses were carried out following IITA (1979) procedures. Soil $\mathrm{pH}$ was determined in distilled water at 1:1 (w/v) soil: water ratio. Percent organic matter was derived by multiplying percent organic carbon by a factor of 1.72 (Broadbent, 1953). Total N was determined by the micro-Kjedahl digestion method. Available P was determined by the Bray's P1 test, using $0.03 \mathrm{NH}_{4} \mathrm{~F}$ in $0.02 \mathrm{~N} \mathrm{HCl}$ as the extractant and measuring extracted $\mathrm{P}$ colorimerically at $660 \mathrm{~nm}$ by the molybdenum blue method (Bray and Kurtz, 1945). Exchangeable bases were determined by extraction with neutral normal $\mathrm{NH}_{4} \mathrm{OAC}$ at a soil: solution ratio of 1:10. Extraction of exchangeable $\mathrm{Ca}, \mathrm{K}, \mathrm{Mg}$ and $\mathrm{Na}$ was with $1 \mathrm{~N}$ ammonium acetate, $\mathrm{pH}$ 7.0, and measured with a flame photometer (Model PFP 7, Jenway, Camlab, Cambridge, UK). Magnesium was determined by atomic absorption spectrophotometry (Model CE 2041-2000 series, Cecil, Hitchin, UK). Exchangeable acidity was determined by titration of $1 \mathrm{M} \mathrm{KCl} \mathrm{extract} \mathrm{against} 0.05 \mathrm{M}$ $\mathrm{NaOH}$ to a pink end point using phenolphthalein as the indicator (McLean, 1982). Soil particle size distribution was determined by a hydrometer method (McLean, 1982), with sodium hexametaphosphate (Calgon) as the dispersing agent. The soil was slightly acidic, with a pH of 6.2. It had an organic matter content of $4.3 \%$. The N, P and $\mathrm{K}$ contents were $2.5 \%, 11.6 \mathrm{mg} \mathrm{kg}^{-1}$ and $0.4 \mathrm{cmol} \mathrm{kg}^{-1}$, respectively. It was a loamy sand (Table 1). The cowdung was slightly alkaline with a pH of 8.1 . It had an organic carbon content of $19.4 \%$. Total nitrogen content was $1.9 \%$ with $\mathrm{P}$ and $\mathrm{K}$ contents of $0.3 \%$ and $2.9 \%$ respectively. The calcium content was $3.4 \%$ (Table 2).

Table 1. Pre-cropping soil analysis

\begin{tabular}{ll}
\hline Property & Value \\
\hline $\mathrm{pH}$ & 6.2 \\
Organic carbon & $0.3 \%$ \\
Organic matter & $4.3 \%$ \\
Total N & $2.5 \%$ \\
Available P & $11.6 \mathrm{mg} \mathrm{kg}^{-1}$ \\
Exchangeable K & $0.4 \mathrm{cmol} \mathrm{kg}^{-1}$ \\
$\mathrm{Na}$ & $0.5 \mathrm{cmol} \mathrm{kg}^{-1}$ \\
$\mathrm{Ca}$ & $4.3 \mathrm{cmol} \mathrm{kg}$ \\
$\mathrm{Sand}$ & $87.2 \%$ \\
Silt & $3.2 \%$ \\
Clay & $9.6 \%$ \\
Texture & Loamy sand \\
\hline
\end{tabular}


Table 2. Manure chemical analysis

\begin{tabular}{ll}
\hline Property & Value \\
\hline $\mathrm{pH}$ & 8.1 \\
Organic carbon & $19.4 \%$ \\
Organic matter & $33.5 \%$ \\
Total N & $1.9 \%$ \\
Available P & $0.3 \%$ \\
Exchangeable K & $2.9 \%$ \\
$\mathrm{Ca}$ & $3.4 \%$ \\
$\mathrm{Na}$ & $0.9 \%$ \\
\hline
\end{tabular}

The experiment was arranged in a randomized complete block design with 7 treatments replicated 3 times. Plot size was $2.7 \times 3.0 \mathrm{~m}$ with $1 \mathrm{~m}$ margin round the plots. Ogun rock phosphate (ORP) was crushed and mixed with the cowdung which was incorporated into the soil at land preparation, two weeks before planting. Combined applications of 2.5; 5.0; 7.5 and $10.0 \mathrm{t} \mathrm{ha}^{-1}$ Cowdung each, with $100 \mathrm{~kg} \mathrm{ha}^{-1}$ ORP were investigated. This was equivalent to: $40 \mathrm{~kg}, 20 \mathrm{~kg}, 13.33 \mathrm{~kg}$ and $10 \mathrm{~kg}$ ORP per ton CD, respectively. There was also a sole application of the ORP and a standard check of NPK 20-10-10 at $400 \mathrm{~kg} \mathrm{ha}^{-1}$ applied 2 weeks after planting with an unfertilized control. Okra seeds of NHAe 47-4 variety were sown in May at $60 \times 60 \mathrm{~cm}$ spacing, 2 weeks after manure application. Plots were manually weeded at 4 weeks after planting, with supplementary hand weeding at 7 WAP. Application of Karate ${ }^{\circledR}$ (lambda-cyhalothrin $2.5 \mathrm{EC}$ ) at $1 \mathrm{~L} \cdot \mathrm{ha}^{-1}$ was done at 6 and $8 \mathrm{WAP}$ to control infestation of beetles.

Data were collected on growth and fruit yield of okra from 6 tagged plants per plot from the inner rows. Plant height, stem diameter, number of leaves/plant and average leaf areas were used to assess plant growth. Plant height was measured from ground level to the growing tip. Plant stem diameter was determined at the $15 \mathrm{~cm}$ height. Numbers of fully-expanded leaves were counted. Leaf area was estimated by the non-destructive method of Olasantan and Salau (2008).

Fresh fruit yield, fruit length and fruit diameter were determined to assess yield. Cumulative pod yield over 4 harvests at 5 days intervals was used to assess fruit yield. Data for the two years were pooled and subjected to analysis of variance using SAS (SAS, 1990). The significant different mean values were separated using DMRT $(\mathrm{p} \leq 0.05)$.

\section{Results}

\subsection{Plant Growth}

Plant heights with 4 weeks growth were similar with the unfertilized plants. Sole ORP had plants even shorter than the unfertilized plants while the tallest plants were from ORP $+5.0 \mathrm{tha}^{-1} \mathrm{CD}$ application. They were however all similar, with a range of 8.9-10.9 cm. (Table 3). By $8 \mathrm{WAP}$, plant heights were different. Plants fertilized with ORP $+10.0 \mathrm{tha}^{-1} \mathrm{CD}$ had taller plants which were only comparable with plants fertilized with ORP $+7.5 \mathrm{tha}^{-1} \mathrm{CD}$.

Plant stem diameters were also comparable at $4 \mathrm{WAP}$, ranging from $15.1-22.4 \mathrm{~mm}$. The unfertilized control plants had the lowest stem diameter while application of ORP $+5.0 \mathrm{tha}^{-1} \mathrm{CD}$ had the highest stem diameter. By 8 WAP, stem diameters were different. Plants treated with ORP mixed with either 7.5 or $10.0 \mathrm{t} \mathrm{ha}^{-1} \mathrm{CD}$ had higher stem diameters than the NPK - fertilized check plants and the unfertilized plants but comparable with the other ORP - treated plants (Table 3).

Average number of leaves per plant at 4 WAP was similar, ranging between 6 and 7 . However, by 8 WAP, ORP + $10.0 \mathrm{tha}^{-1} \mathrm{CD}$ application had higher number of leaves per plant which was only comparable with ORP $+5.0 \mathrm{tha}^{-1}$ $\mathrm{CD}$ application (Table 3). The NPK - fertilizer check plants and the unfertilized plants had lower number of leaves per plant than all the ORP - treated plants (Table 3).

Average leaf areas per plant were different with 4 weeks growth, with ORP +7.5 or $10.0 \mathrm{t} \mathrm{ha}^{-1} \mathrm{CD}$ giving higher average leaf areas. ORP $+5 . \mathrm{O}$ or $2.5 \mathrm{tha}^{-1}$ had lower but comparable leaf areas. The NPK- fertilized check and the unfertilized plants had even lower leaf areas. By $8 \mathrm{WAP}$, average leaf areas were generally higher, maintaining almost same trend as at $4 \mathrm{WAP}$. The highest was still from ORP $+10.0 \mathrm{tha}^{-1} \mathrm{CD}$. Applications of ORP with lower 
CD of 7.5; 5.0 and $2.5 \mathrm{tha}^{-1}$ had comparable leaf areas. Both the NPK- fertilized and the unfertilized control plants had significantly lower leaf areas (Table 3 ).

Table 3. Okra growth parameters with ORP-amended cowdung

\begin{tabular}{|c|c|c|c|c|c|c|c|c|}
\hline & \multicolumn{2}{|c|}{ Plant height $(\mathrm{cm})$} & \multirow{2}{*}{$\begin{array}{l}\text { Stem } \\
(\mathrm{mm})\end{array}$} & \multirow{2}{*}{$\begin{array}{l}\text { diameter } \\
8\end{array}$} & \multicolumn{2}{|c|}{$\begin{array}{l}\text { Av. No. of leaves } \\
\text { plant }\end{array}$} & \multicolumn{2}{|c|}{ Av. Leaf area $\left(\mathrm{cm}^{2}\right)$} \\
\hline & 4 & 8 & & & 4 & 8 & 4 & $8 \mathrm{WAP}$ \\
\hline No Fertilizer & 9.57 & $17.21 \mathrm{e}$ & 15.1 & $42.2 \mathrm{~b}$ & 5.53 & $9.45 \mathrm{~d}$ & $63.46 \mathrm{~d}$ & $391.20 \mathrm{c}$ \\
\hline ORP & 8.90 & 20.63de & 16.1 & $56.0 \mathrm{ab}$ & 6.13 & $14.21 \mathrm{c}$ & $87.70 \mathrm{c}$ & $673.50 \mathrm{~b}$ \\
\hline $\mathrm{ORP}+2.5 \mathrm{tha}^{-1} \mathrm{CD}$ & 10.79 & $25.54 \mathrm{~cd}$ & 21.7 & $62.9 \mathrm{ab}$ & 6.87 & $15.56 \mathrm{c}$ & $129.10 \mathrm{~b}$ & $759.50 \mathrm{ab}$ \\
\hline $\mathrm{ORP}+5.0 \mathrm{tha}^{-1} \mathrm{CD}$ & 10.93 & $29.36 b c$ & 22.4 & $64.5 \mathrm{ab}$ & 7.13 & $16.88 \mathrm{bc}$ & $132.90 \mathrm{~b}$ & $877.40 \mathrm{ab}$ \\
\hline $\mathrm{ORP}+7.5 \mathrm{t} \mathrm{ha}^{-1} \mathrm{CD}$ & 10.66 & $35.98 \mathrm{ab}$ & 17.6 & $69.9 \mathrm{a}$ & 6.67 & $18.83 \mathrm{ab}$ & $150.60 \mathrm{a}$ & $903.60 \mathrm{ab}$ \\
\hline $\begin{array}{l}\text { ORP }+10.0 \mathrm{tha}^{-1} \\
\mathrm{CD}\end{array}$ & 9.76 & $36.93 a$ & 18.9 & $70.8 \mathrm{a}$ & 6.73 & $21.80 \mathrm{a}$ & $159.18 \mathrm{a}$ & $951.20 \mathrm{a}$ \\
\hline NPK Fertilizer & $9.11 \mathrm{NS}$ & $17.43 \mathrm{e}$ & $13.2 \mathrm{NS}$ & $43.9 \mathrm{~b}$ & $5.62 \mathrm{NS}$ & $10.95 \mathrm{~d}$ & $60.21 \mathrm{~d}$ & $428.60 \mathrm{c}$ \\
\hline
\end{tabular}

NS: Values not significantly different $(\mathrm{P} \leq 0.05)$; CD: Cowdung; WAP: Weeks after planting.

\subsection{Fruit Yield}

Application of ORP $+10.0 \mathrm{tha}^{-1} \mathrm{CD}$ gave the highest okra fresh pod yield which was comparable with yields from lower rates of cowdung. Sole ORP and the NPK - fertilizer check gave similar yields which were higher than yield from the unfertilized plants (Table 4).

Pod length was significantly higher with ORP +10.0 or $7.5 \mathrm{tha}^{-1} \mathrm{CD}$. Pods from $5.0 \mathrm{t} \mathrm{ha}^{-1} \mathrm{CD}$ were comparable only with pods from $7.5 \mathrm{tha}^{-1} \mathrm{CD}$. Application of ORP $+2.5 \mathrm{tha}^{-1} \mathrm{CD}$ had shorter pods which were longer than pods from sole ORP and pods from NPK fertilizer. The unfertilized plants had even shorter pods.

Table 4. Okra fresh pod yield and yield components with ORP - amended cowdung

\begin{tabular}{|c|c|c|c|c|}
\hline & Yield $\left(\mathrm{t} \mathrm{ha}^{-1}\right)$ & $\begin{array}{l}\text { Fruit } \\
(\mathrm{cm})\end{array}$ & length & Fruit Circumference $(\mathrm{cm})$ \\
\hline No Fertilizer & $0.98 \mathrm{c}$ & $5.13 \mathrm{e}$ & & $5.42 \mathrm{e}$ \\
\hline ORP & $1.39 \mathrm{~b}$ & $6.14 \mathrm{~d}$ & & $6.03 \mathrm{~d}$ \\
\hline $\mathrm{ORP}+2.5 \mathrm{tha}^{-1} \mathrm{CD}$ & $2.92 \mathrm{a}$ & $7.41 \mathrm{c}$ & & $7.58 \mathrm{c}$ \\
\hline $\mathrm{ORP}+5.0 \mathrm{tha}^{-1} \mathrm{CD}$ & $2.99 \mathrm{a}$ & $8.17 \mathrm{~b}$ & & $8.48 b$ \\
\hline $\mathrm{ORP}+7.5 \mathrm{t} \mathrm{ha}^{-1} \mathrm{CD}$ & $3.05 \mathrm{a}$ & $8.86 \mathrm{ab}$ & & $9.23 \mathrm{a}$ \\
\hline $\mathrm{ORP}+10.0 \mathrm{tha}^{-1} \mathrm{CD}$ & $3.27 \mathrm{a}$ & $9.43 \mathrm{a}$ & & $9.73 \mathrm{a}$ \\
\hline NPK Fertilizer & $1.40 \mathrm{~b}$ & $6.66 \mathrm{~d}$ & & $6.23 \mathrm{~d}$ \\
\hline
\end{tabular}

Values with same letter in a column are not significantly different (DMRT $\leq 0.05$ ); CD: Cowdung.

Pod circumference was also highest from ORP $-10.0 \mathrm{tha}^{-1} \mathrm{CD}$ and was comparable only with pods from ORP $7.5 \mathrm{t} \mathrm{ha}^{-1} \mathrm{CD}$. Pod circumference decreased as the quantity of cowdung in mixture decreased. Sole ORP application and NPK-fertilized plants had lower but comparable pod circumferences. Plants from the unfertilized control treatment had lower pod circumference than all the fertilized plants (Table 4).

\section{Discussion}

The low nutrient status of the soil is a result of previous years' consecutive croppings. This however, qualifies it for a study on crop response to the rock phosphate. The cowdung was only moderate in nutrient contents and therefore will require fortification to support cropping. The phosphorous content was not high and so, has the potentials to show response to the rock phosphate. Sole application of ORP or NPK fertilizer was not able to support optimum 
plant growth but complemented ORP and cowdung, indicating better nutrient use efficiency with the complemented sources. This agrees with earlier observations of Akande et al. (2005), Akande et al. (2011) that crop growth is better supported with complemented ORP and cowdung. Nutrients seemed not released fast enough from all the fertilizer sources to effect a difference with the unfertilized plants with 4 weeks of growth. This will account for the observed similar plant height, stem diameter and number of leaves per plant. It however seemed early enough to effect difference in leaf area expansion. High concentration of ORP, up to $20 \mathrm{~kg}$ per ton CD seemed not favourable for early leaf area expansion. 8 weeks seemed good enough time to enable optimum plant growth. Fortifying cowdung with not more than $13 \mathrm{~kg}$ per ton CD seemed adequate for supporting plant height, number of leaves and leaf area development.

Cultivating okra with sole ORP on a soil with $2.5 \% \mathrm{~N}$ and $0.34 \mathrm{cmol} \mathrm{kg}^{-1} \mathrm{~K}$ in the tropics gives comparable yield as NPK fertilizer application. However, complementing a ton of cowdung with $10-40 \mathrm{~kg}$ ORP gives higher okra fruit yields. Both the growth and the yield of okra were more favoured as the dilution of the rock phosphate was increased with higher rates of cowdung. Similar increase in okra yield with fortified organic manure application has been reported by Akande et al., 2005. Crop yields increase has been reported to be a benefit derived from phosphate applications (Yusuf et.al, 2003).

Optimum okra fresh pod yield is supported with $100 \mathrm{~kg}$ ORP mixed with $10.0 \mathrm{t} \mathrm{ha}^{-1}$ Cowdung.

\section{References}

Adepetu, J. A. (1993). Phosphorus fertilization of tropical crops. In J. Eszman, H. Mutscher, \& T. Franke (Eds), Nutrients supply to tropical crops (pp. 211-288). Inst. of Trop. Agric. Leipzig Publications.

Adetunji, M. T. (1991). An evaluation of the soil nutrient status for maize production in South-western Nigeria. Samaru J. Agric. Res., 8, 101-113.

Adetunji, M. T. (1994). Phosphorus requirement of a maize-cowpea sequential cropping on a Paleudult. Fert. Res., 39, 161-166.

Adetunji, M. T. (2005). Soil quality for ecological security and sustainable agriculture. UNAAB Inaugural Lecture, Series. No.19. University of Agriculture, Abeokuta, Nigeria. http://dx.doi.org/10.1007/BF00750243

Akande, M. O. (2005). Response of maize and cowpea grown sequentially to direct application of phosphate rock. $\mathrm{Ph} . \mathrm{D}$ Thesis. University of Agriculture, Abeokuta, Nigeria.

Akande, M. O., Adediran, J. A., \& Oluwatoyinbo, F. I. (2005). Effects of rock phosphate amended with poultry manure on soil available $\mathrm{P}$ and yield of maize and cowpea. Afr. J. Biotechnology, 4(3), 444-448.

Akande, M. O., Makinde, E. A., \& Adetunji, M. T. (2011). Response of Maize and Cowpea Grown Sequentially to Application of Phosphate Rock in the Humid Tropics. Comm. Soil Sci. Plt. Anal, 42(9), 1027-1037. http://dx.doi.org/10.1007/BF00750243

Akande, M. O., Oluwatoyinbo, F. I., Adediran, J. A., Buari, K. W., \& Yusuf, I. O. (2003). Soil amendments affect the Release of P from rock phosphate and the development and Yield of Okra. J. Veg. Crop Prod., 19, 3-9.

Bangar, K. C., Yadav, K. S., \& Mishra, M. M. (1985). Transformation of rock phosphate during composting and the effect of humic acid. Plant Soil., 85, 259-266. http://dx.doi.org/10.1007/BF02139630

Bouyoucos, G. J. (1962). Hydrometer methods improved for making particle size analysis of soils. Soils Science of America Proceeding, 26, 464-465.

Bray, R. M., \& Kurtz, L. T. (1945). Determination of total organic P and available forms of phosphorus in soils. Soil Sci., 59, 39-45. http://dx.doi.org/10.1097/00010694-194501000-00006

Broadbent, F. E. (1953). The soil organic fraction. Adv. Agron., 5, 153-183. http://dx.doi.org/10.1016/S0065-2113(08)60229-1

International Institute of Tropical Agriculture (IITA). (1979). Selected methods for soil and plant analysis, Manual series No 1. IITA, Ibadan, Nigeria.

Mclean, E. O. (1982). Soil pH and lime requirement. In Methods of soil analysis (Part.2. Agron. 9, 2nd Ed., pp. 199-224) ASA, SSSA, Madison, Wisc.

Nnadi, L. A., \& Haque, I. (1998). Agronomic effectiveness of rock phosphate in an Andept of Ethiopia. Comm. Soil Sci. Plant Anal., 19, 79-90. http://dx.doi.org/10.1080/00103628809367921 
Olasantan, F. O., \& Salau, A. W. (2008). Effect of pruning on growth, leaf yield and pod yields of okra (Abelmoschus esculentus (L.) Moench. J. Agric. Sci. (Cambridge), 146, 93-102. http://dx.doi.org/10.1017/S0021859607007290

Singh, C. P., \& Amberger, A. (1990). Solubilization and availability of phosphorus during decomposition of rock phosphate enriched straw and urine. Biol. Agric. Hort., 7, 261-269. http://dx.doi.org/10.1080/01448765.1991.9754553

Statistical Analyses Institute (SAS). (1990). Statistical Analysis System SA/STAT Users' Guide (Version 6, 4th ed.). NC: SAS Institute, Cary.

Yusuf, A. A., Chude, V. O., \& Janassen, B. H. (2003). Response of rice (Oryza sativa. L) to phosphate fertilizers varying in solubility. Afr. Soils., 33, 57- 72.

\section{Copyrights}

Copyright for this article is retained by the author(s), with first publication rights granted to the journal.

This is an open-access article distributed under the terms and conditions of the Creative Commons Attribution license (http://creativecommons.org/licenses/by/3.0/). 